\title{
Physiologic Specialization of Puccinia triticina on Wheat in the United States in 2000
}

\author{
D. L. Long, Plant Pathologist, J. A. Kolmer, Research Plant Pathologist, K. J. Leonard, Research Plant Patholo- \\ gist, and M. E. Hughes, Biologist, Cereal Disease Laboratory, USDA-ARS, Department of Plant Pathology, Uni- \\ versity of Minnesota, 1551 Lindig St., St. Paul 55108
}

\begin{abstract}
Long, D. L., Kolmer, J. A., Leonard, K. J., and Hughes, M. E. 2002. Physiologic specialization of Puccinia triticina on wheat in the United States in 2000. Plant Dis. 86:981-986.

Collections of Puccinia triticina were obtained from rust infected wheat leaves by cooperators throughout the United States and from surveys of wheat fields and nurseries in the Great Plains, Ohio Valley, Gulf Coast, and Atlantic Coast States in order to determine the virulence of the wheat leaf rust fungus in 2000. Single uredinial isolates $(1,120$ in total) were derived from the wheat leaf rust collections and tested for virulence phenotype on 16 lines of Thatcher wheat that are near-isogenic for leaf rust resistance genes. In the United States in 2000, 54 virulence phenotypes of $P$. triticina were found. Virulence phenotypes MBDS and MCDS, which are virulent to resistance gene $L r 17$, were the first and third most common phenotypes in the United States and were found in the Great Plains and the Ohio Valley regions. MCRK, which is virulent to Lr26, was the second most common phenotype and was found primarily in the Southeast, Ohio Valley, and Northeast regions. In the northern area of the Great Plains, phenotypes with virulence to Lr16 increased in frequency from 1998 and 1999. The Southeast and Great Plains regions had different predominant virulence phenotypes, which indicates that populations of $P$. triticina in those areas are not closely connected. The northern and southern areas of the Great Plains region had the same predominant virulence phenotypes, indicating movement of virulence phenotypes of $P$. triticina within this region.
\end{abstract}

Additional keywords: epidemiology, Puccinia recondita f. sp. tritici, wheat leaf rust

Wheat leaf rust, caused by the fungus Puccinia triticina Eriks., occurs nearly wherever wheat is grown in the United States. The use of wheat cultivars with genetic resistance to leaf rust is the most practical method of controlling this disease. Effective leaf rust resistance in wheat cultivars is dependent on the virulence of the regional populations of $P$. triticina; however, many different races or virulence phenotypes of $P$. triticina are found in the different wheat growing regions of North America. The use of wheat cultivars with specific leaf rust resistance genes selects for phenotypes of $P$. triticina that have virulence to the resistance gene. Although more than 45 leaf rust resistance genes have been described (14), many of the genes do not condition effective resistance since races of $P$. triticina with virulence to the genes are common. Distinct regional populations of $P$. triticina have evolved in North America due to the use of different

Corresponding author: J. A. Kolmer

E-mail: jkolmer@cdl.umn.edu

Accepted for publication 26 April 2002.

Publication no. D-2002-0625-01R

This article is in the public domain and not copyrightable. It may be freely reprinted with customary crediting of the source. The American Phytopathological Society, 2002. leaf rust resistance genes in the different wheat classes that are grown across the continent (3).

Wheat leaf rust virulence surveys have been conducted by the Cereal Disease Laboratory, formerly known as the Cereal Rust Laboratory, since 1978 to detect new virulence phenotypes and to monitor shifts of virulence phenotypes in major wheat growing regions of the United States $(11,13)$. Similar surveys have been done in Canada since $1931(1,2,5)$ and in Mexico (15). In the United States (8) and Canada (3), leaf rust survey data have been used to characterize virulence and race dynamics and phenotypic diversity within and between wheat growing regions.

The objectives of this study were to characterize the virulence of populations of P. triticina in the United States in 2000 to the North American wheat leaf rust differentials (10) and to compare these results with those of previous surveys.

\section{MATERIALS AND METHODS}

Collections and virulence identification. Uredinial collections of leaf rust were made from wheat in annual surveys (over routes totaling approximately $20,000 \mathrm{~km}$ ) of the Great Plains, Ohio Valley, Gulf Coast, and southeastern states, and by cooperators throughout the United States. In 2000 , field surveys of wheat were made in southern and central Georgia (late March through May); eastern and southern Texas (early April); northern Texas and south central Oklahoma (late April); southeastern Gulf Coast (mid-April to early May); southeastern states (late April to early May); Oklahoma and Kansas (mid-May); the Ohio River Valley (early June); north central Kansas, Nebraska, western Iowa, South Dakota, and southern Minnesota (mid-June); and northern Plains states (early July and again in late July). Visual inspections for the presence of rust were made in commercial fields (4 to 50 ha in size) every $32 \mathrm{~km}$ or in the first field thereafter. Additional collections were made in wheat breeding nurseries, trap plots, and demonstration plots along the route. Nurseries typically contain a wide array of leaf rust resistance phenotypes, including breeding lines with leaf rust resistance genes not yet in commercial cultivars. Trap plots usually contain older cultivars of wheat no longer prominent in commercial production. A collection consisted of one to several leaves with uredinia from a single plant or cultivar. The leaves were air-dried and stored at $4^{\circ} \mathrm{C}$ until spores were collected for inoculations. Collections from inoculated nurseries were not included in the study.

Urediniospores from each collection were used to inoculate 7-day-old seedlings of the wheat cultivar Thatcher (CI 10003) that were treated at emergence with $0.01 \mathrm{~g}$ of maleic hydrazide (dissolved in $30 \mathrm{ml}$ of $\mathrm{H}_{2} \mathrm{O}$ ) per pot to enhance spore production. Plants were sprayed with approximately $0.5 \mathrm{ml}$ per pot of 10 to 20 seedlings with a suspension of spores in lightweight mineral oil. Inoculated plants were placed in a dew chamber overnight at $18^{\circ} \mathrm{C}$. The plants were then transferred to a greenhouse where temperatures varied between 18 and $28^{\circ} \mathrm{C}$ daily under at least $8 \mathrm{~h}$ of natural light. After 12 to 15 days, pots were thinned to three seedlings per collection, and the primary leaf of each plant was trimmed to isolate a single uredinium. Six to 9 days later, a cyclone spore collector was used to collect urediniospores separately from one or two single uredinia per collection. If the single uredinia were small and few spores were collected, the isolates were increased through one uredinial generation on seedlings of Thatcher before inoculating differential lines. Otherwise, spores from the single uredinia were mixed with $0.5 \mathrm{ml}$ of oil and atomized onto 7 - to 
8-day-old plants of the differential host series (five to seven plants per line) of near-isogenic lines of Thatcher with single resistance genes $L r 1, L r 2 a, L r 2 c, L r 3$, Lr3ka, Lr9, Lr10, Lr11, Lr14a, Lr16, Lr17, $L r 18, L r 24, L r 26, L r 30$, and $L r B$. Wheat lines with genes $L r 1, L r 2 a, L r 2 c, L r 3$, and Lrll were also in the early wheat leaf rust differential sets that were used in the United States and Canada from the 1930s to 1960 s $(2,10)$. The 16 differential lines in the present day set account for a large part of the diversity of $P$. triticina in North America. Sets of differential lines grown during June through September received no supplemental light. From October through May, natural daylight was supplemented with high-pressure sodium lamps from 0700 to 2300 (400 to $450 \mu \mathrm{E} \cdot \mathrm{m}^{-2} \cdot \mathrm{s}^{-1}$ at bench level). After 10 to 14 days, infection types were recorded as either high (IT 3-4) or low (IT $0-2+$ ) as in previous surveys (9-13). Race designations were assigned as described by Long and Kolmer (10). A four-letter code describes the low or high infection types of each isolate to the 16 differential lines. Each letter corresponds to the infection types of four differentials. The Thatcher lines with genes $L r l$, $L r 2 a, L r 2 c$, and $L r 3$ were the four lines in the first set of differentials; lines with genes $\operatorname{Lr} 9, \operatorname{Lr} 16, \operatorname{Lr} 24$, and $\operatorname{Lr} 26$ were the second set of differentials; lines with genes Lr3ka, Lr11, Lr17, and Lr30 were the third set of differentials; and lines with genes $L r B, L r 10, L r 14 a$, and $L r 18$ were the fourth set of differentials. This is the first year in the survey of $P$. triticina in the United States where a fourth set of differentials has been used. The same fourth set of differentials has been used in surveys of $P$. triticina in Canada $(4,7)$.

Race and virulence frequencies were determined for collections from seven of eight agroecological geographic areas (Fig. 1): area 1, mainly southern-adapted soft red winter wheats; areas 2 and 3, mostly northern-adapted soft red and white winter wheat; area 4, mixed wheat types but primarily hard red winter; area 5, hard red winter wheat; area 6 , mixed wheat types but primarily hard red spring and durum; area 7, spring wheats planted in late fall; and area 8 , mixed wheat types but primarily soft white winter. There were no collections from area 8 in 2000.

\section{RESULTS}

Incidence and severity of leaf rust. In the Great Plains region, leaf rust was light on the susceptible cultivar TAM-107 in early February in central Texas. By the third week of March, rust severity was $40 \%$ on lower leaves of susceptible cultivars in southern Texas. From late April to early May, leaf rust severities on susceptible wheats in central Texas to Oklahoma ranged from trace to $80 \%$. In Kansas, leaf rust severities were at a trace to $10 \%$ in early April in the southern part of the state. By the last 2 weeks in May, leaf rust severities in fields ranged from trace to $40 \%$. In breeding plots, infection levels were as high as $80 \%$. The statewide estimated yield loss due to wheat leaf rust in Kansas was 2.9\%. In winter wheat plots in Minnesota, leaf rust infections that had overwintered were first observed on April 27. By midJune, leaf rust severities of $20 \%$ were reported on flag leaves of susceptible spring and winter wheat in North Dakota. In late July, leaf rust severities were trace to $10 \%$ in spring wheat fields and trace to $80 \%$ in breeding plots in North Dakota and Minnesota. In the north central states, yield loss due to leaf rust was estimated to be 1 to $2 \%$.

In the southeastern states, leaf rust infections were initially found in early February

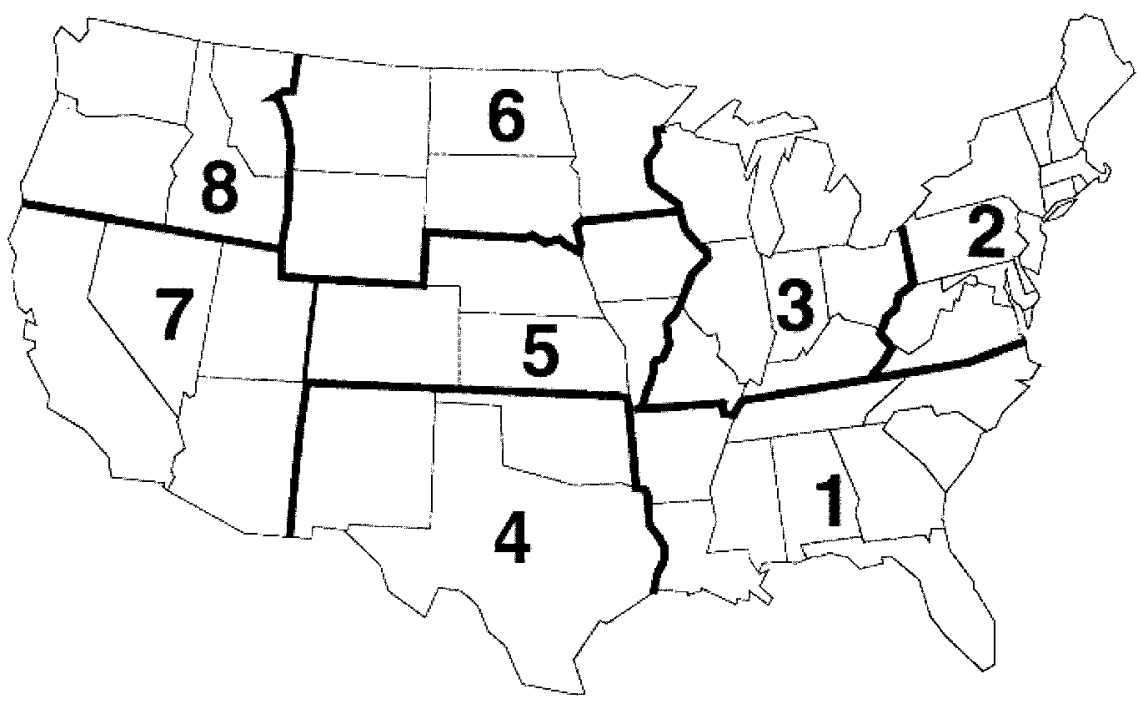

Fig. 1. Agroecological areas for Puccinia triticina in the United States. Winter wheat is grown in areas 1 to 5 and 8; spring wheat is grown in areas 6 and 7. Hard red wheat cultivars are grown in areas 4 to 6; soft red or white cultivars in areas 1 to 3 ; and mainly soft white cultivars in area 8. See text for greater detail. in Louisiana. By late March, leaf rust infections were severe in breeding plots in Louisiana and in west central Mississippi. From northern Florida to North Carolina, leaf rust infections were first observed in mid to late March. Wheat plots in South Carolina had 30 to $50 \%$ infection levels in mid-April. In the southeastern states, susceptible wheat lines had leaf rust severities of $80 \%$ in plots and $20 \%$ in fields by early May. In North Carolina, maximum severity levels were over $80 \%$ by the second week of May on susceptible wheat lines in breeding plots. In fields in North Carolina, infection levels were at a trace to $20 \%$ due to the use of leaf rust resistant cultivars. In New York, leaf rust infections were first observed in mid-June.

In early June, leaf rust severities of $40 \%$ occurred in plots of susceptible winter wheat, and from trace to $10 \%$ in fields from Northeast Missouri to Ohio. By midJune, trace levels of leaf rust were observed on winter wheat in southern Wisconsin. In California, leaf rust severities were 20 to $80 \%$ in early to mid-May. In early July in eastern Washington, leaf rust severities were 60 to $70 \%$ on susceptible wheat lines in breeding plots and at lower levels in fields. A complete summary of yield losses due to leaf rust in 2000 (9) and wheat leaf rust occurrence and severity in the United States can be found at the Cereal Disease Laboratory website.

Distribution of virulence phenotypes. Fifty-four virulence phenotypes of $P$. triticina found in the United States in 2000 are listed in Table 1. The single uredinial isolates $(1,120$ in total) of $P$. triticina derived from collections made in the United States in 2000 were tested for virulence to the Thatcher near-isogenic lines (Table 2). Phenotypes MBDS (22.7\%), MCDS $(10.4 \%)$, and MCRK (12.2\%) were the three most common virulence phenotypes in the United States in 2000.

In the southeastern states (area 1), 25 virulence phenotypes were identified. MCRK, MBRK, and TLGF were the three most common phenotypes accounting for $58.8 \%$ of isolates from area 1 . In the Northeast states (area 2), eight virulence phenotypes were identified, with MCRK, TLGF, MCBS, and MBRJ accounting for $70.3 \%$ of isolates in this region. In the Ohio Valley states (area 3), 20 virulence phenotypes were identified, with MBDS, MBRK, and MCRK phenotypes accounting for $49 \%$ of isolates. A significant movement of $P$. triticina urediniospores must occur between areas 1, 2, and 3 . MCRK was a common phenotype in all three of these areas, while MBRK was common in areas 1 and 3, and TLGF was common in areas 1 and 2 .

In the Great Plains region (areas 4, 5, and 6), phenotypes MBDS and MCDS were the two most common phenotypes in all three areas, accounting for $41.7 \%$ of isolates in area $4,91.4 \%$ of isolates in area 
5 , and $54.7 \%$ of isolates in area 6 . The Great Plains region of areas 4, 5, and 6 is an interconnected epidemiological zone for $P$. triticina virulence phenotypes in the United States. There were also some differences in phenotype distribution among the three areas of the Great Plains region. For example, TFBJ occurred at $9.8 \%$ in area 4 and was at lower frequencies in areas 5 and 6. Phenotype THBJ occurred at $13.7 \%$ in area 6 , but was not found in areas 4 or 5 . Twenty-two, 5 , and 21 virulence phenotypes of $P$. triticina were found in areas 4, 5, and 6, respectively. In California (area 7), five virulence phenotypes were found. Phenotype MBGJ at $75 \%$ and TBRJ at $11.1 \%$ were the most common phenotypes from area 7 .

Virulence frequencies. Frequencies of virulence differed among populations of $P$. triticina in the United States in 2000 (Table 3). Virulence to $\operatorname{Lr} 2 a$ was at 5.4 and $11.1 \%$ of the isolates in area 5 and 7 , respectively, while virulence to $L r 2 a$ in areas $1,2,3,4$, and 6 ranged from 25.9 to $49.1 \%$. Virulence to $L r 2 c$ is highly associated with virulence to $\operatorname{Lr} 2 a$. Virulence frequencies to $L r 2 c$ were higher than virulence frequencies to $L r 2 a$ in areas 1,2 , and 3. Virulence frequencies to $L r 2 a$ and $L r 2 c$ were the same in areas 4, 5, 6, and 7.

Virulence to $\operatorname{Lr} 9$ ranged from 7.4 to $28.3 \%$ in areas $1,2,3$, and 4 , but was at less than $1 \%$ in area 6 and was not detected in areas 5 and 7 . Soft red winter wheat cultivars with $\operatorname{Lr} 9$ are commonly grown in areas 1, 2, and 3. Virulence to Lrl6 was found only in area 6 , where a number of hard red spring wheat cultivars have this resistance gene. Virulence to $L r 24$ was $30.1 \%$ in area 4 , where hard and soft red winter wheat cultivars have this gene. Virulence to $L r 24$ was less than $12 \%$ in the other regions. Virulence to $L r 26$ was $19.4 \%$ in area $5,57.1 \%$ in area 6 , and less than $6 \%$ in area 7 . Winter wheat cultivars with $L r 26$ are grown in areas 1, 3, 4, and 5.

Virulence to $L r 3 k a$ was 51.9 to $73.4 \%$ in areas 1, 2, and 3, and was 24.5 and $8.6 \%$ in areas 4 and 5, respectively. Hard red winter wheat cultivars with $L r 3 k a$ have been grown in areas 4 and 5. Virulence to $L r 3 \mathrm{ka}$ was 3.3 and $13.9 \%$ in areas 6 and 7 , respectively. Virulence to Lr30 is highly associated with virulence to $L r 3 k a$, differing in frequency only in area 6 , where $2.7 \%$ of isolates were virulent to $\operatorname{Lr} 30$.

Virulence to $\mathrm{Lrll}$ was 57.4 to $89.1 \%$ in areas $1,2,3$, and 7 . Soft red winter wheat cultivars with $\mathrm{Lrll}$ are grown in areas 1,2, and 3. Virulence to $\mathrm{Lrll}$ was lower in areas 4 , 5, and 6, ranging from 8.6 to $20.9 \%$. Virulence to $\mathrm{Lr} 17$ ranged from 25 to $91.4 \%$ in areas 3, 4, 5, and 6, and was less than $6 \%$ in areas 1,2 , and 7 . Hard red winter wheat cultivars with $\mathrm{Lr} 17$ are grown in areas 4 and 5 . Gene $\operatorname{LrB}$ is not known to be present in wheat cultivars grown in the United States; however, virulence to this gene ranged from $91.4 \%$ in area 5 to less than $6 \%$ in areas 1 and 7 . Virulence to $\operatorname{Lr} 18$ ranged from 38 to $66.9 \%$ in areas 1,2 , and 3 , and was less than $5 \%$ in areas $4,5,6$, and 7. Soft red winter wheat cultivars with Lr18 are grown in areas 1, 2, and 3. Genes $L r 1, L r 3, L r 10$, and LrI4a are present in winter and spring wheat cultivars across the United States. Virulence frequencies to these genes are high due to their widespread occurrence in different wheat cultivars.

\section{DISCUSSION}

Results from previous surveys have shown that regional populations of virulence phenotypes of $P$. triticina exist in North America $(3,8)$. This regional distribution of virulence phenotypes was also apparent in 2000 in the United States. Widespread planting of wheat cultivars with different leaf rust resistance genes has selected different virulence phenotypes that have resulted in a regionally heterogeneous population of $P$. triticina in North America. In the United States, MBDS and MCDS, the first and third most common phenotypes of $P$. triticina in 2000, have increased steadily since 1996 . Both of these phenotypes are virulent to $\mathrm{Lr} 17$, which is in the Kansas wheat cultivar Jagger that was released in 1995. Phenotype MBDS comprised $13,9,4$, and $1 \%$ of the population of P. triticina in the United States in 1999, 1998,1997 , and 1996, respectively $(11,12)$. MCDS comprised 12, 8, 4, and $0.3 \%$ of isolates in the United States in 1999, 1998, 1997, and 1996, respectively. In 2000, MBDS was found in areas 3, 4, 5, and 6; MCDS was found in areas 1, 3, 4, 5, and 6. Previous to 2000, MBDS and MCDS were not found in the Ohio Valley states of area 3. MBDS and MCDS are also virulent to gene $\operatorname{Lr} B$, which accounts for greater than $50 \%$ of the virulence to this gene in areas 4,5 , and 6 .

In the southeastern states of area 1 , phenotypes MCRK, MBRK, and TLGF were the three most common phenotypes in 2000, as well as in 1999. MBRK and MCRK have been selected by wheat cultivars with $L r 10$ or $L r 11$, such as FFR 555W and Saluda. TLGF has been selected by soft red winter wheat cultivars with combinations of $\operatorname{Lr} 2 a, \operatorname{Lr} 9$, and $\operatorname{Lr} 18$. Phenotype MCRK is also virulent to wheat cultivars with $L r 26$ that are also planted in this region. The lower frequencies of MBRK, MCRK, and TLGF in the Great Plains region of areas 4,5 , and 6 indicate that there is relatively little movement of urediniospores of $P$. triticina from the southeastern states into the Great Plains region. Phenotypes MBRK, MCRK, and TLGF may also be found in lower frequencies in the Great Plains due to fitness disadvantages in the absence of wheat cultivars which these phenotypes are collected from in area 1.

In the Ohio Valley states of area 3, MBDS, MBRK, and TLGF were the three most common phenotypes. The states in area 3 must receive urediniospore inoculum of $P$. triticina from infected wheat fields in areas 1 and 4, since MBRK and TLGF were common phenotypes in area 1 , and MBDS was the most common phenotype in area 4.

Areas 5 and 6 must also receive urediniospore inoculum from $P$. triticina-infected wheat fields in area 4, since MBDS and MCDS were the first and second most common phenotypes in all three areas in

Table 1. Virulence phenotype designations and virulences for Puccinia triticina isolates from the United States in 2000

\begin{tabular}{|c|c|}
\hline $\begin{array}{l}\text { Virulence } \\
\text { phenotype }^{\text {a }}\end{array}$ & $\begin{array}{l}\text { Virulences } \\
\text { (ineffective } L r \text { genes) }\end{array}$ \\
\hline DBBK & $2 c, 10,14 a, 18$ \\
\hline FBMT & $2 \mathrm{c}, 3,3 \mathrm{ka}, 30, \mathrm{~B}, 10,14 a, 18$ \\
\hline LBBR & $1, B, 10,18$ \\
\hline MBBJ & $1,3,10,14 a$ \\
\hline MBDJ & $1,3,17,10,14 a$ \\
\hline MBDS & $1,3,17, B, 10,14 a$ \\
\hline MBGJ & $1,3,11,10,14 a$ \\
\hline MBNJ & $1,3,3 \mathrm{ka}, 17,10,14 a$ \\
\hline MBRJ & $1,3,3 \mathrm{ka}, 11,30,10,14 a$ \\
\hline MBRK & $1,3,3 \mathrm{ka}, 11,30,10,14 a, 18$ \\
\hline MBRS & $1,3,3 \mathrm{ka}, 11,30, B, 10,14 a$ \\
\hline MCBS & $1,3,26, B, 10,14 a$ \\
\hline MCDS & $1,3,26,17, B, 10,14 a$ \\
\hline MCMJ & $1,3,26,3 \mathrm{ka}, 30,10,14 a$ \\
\hline MCRK & $1,3,26,3 \mathrm{ka}, 11,30,10,14 \mathrm{a}, 18$ \\
\hline MDBJ & $1,3,24,10,14 a$ \\
\hline MDMJ & $1,3,24,3 \mathrm{ka}, 30,10,14 a$ \\
\hline MDRJ & $1,3,24,3 \mathrm{ka}, 11,30,10,14 a$ \\
\hline MDRK & $1,3,24,3 \mathrm{ka}, 11,30,10,14 \mathrm{a}, 18$ \\
\hline PBGR & $1,2 c, 3,11, B, 10,18$ \\
\hline PCMR & $1,2 c, 3,26,3 \mathrm{ka}, 30, \mathrm{~B}, 10,18$ \\
\hline PCRK & $1,2 c, 3,26,3 \mathrm{ka}, 11,30,10,14 a, 18$ \\
\hline PNMQ & $1,2 c, 3,9,24,3 \mathrm{ka}, 30, B, 10$ \\
\hline TBBJ & $1,2 a, 2 c, 3,10,14 a$ \\
\hline TBDS & $1,2 a, 2 c, 3,17, B, 10,14 a$ \\
\hline TBRJ & $1,2 a, 2 c, 3,3 \mathrm{ka}, 11,30,10,14 a$ \\
\hline TBRK & $1,2 a, 2 c, 3,3 \mathrm{ka}, 11,30,10,14 a, 18$ \\
\hline TCBB & $1,2 a, 2 c, 3,26$ \\
\hline TCBJ & $1,2 a, 2 c, 3,26,10,14 a$ \\
\hline TCBS & $1,2 a, 2 c, 3,26, B, 10,14 a$ \\
\hline TCDS & $1,2 a, 2 c, 3,26,17, B, 10,14 a$ \\
\hline TCMJ & $1,2 a, 2 c, 3,26,3 k a, 30,10,14 a$ \\
\hline TCMS & $1,2 a, 2 c, 3,26,3 \mathrm{ka}, 30, \mathrm{~B}, 10,14 a$ \\
\hline TCRJ & $1,2 a, 2 c, 3,26,3 \mathrm{ka}, 11,30,10,14 a$ \\
\hline TCRK & $1,2 a, 2 c, 3,26,3 \mathrm{ka}, 11,30,10,14 a, 18$ \\
\hline TDBJ & $1,2 a, 2 c, 3,24,10,14 a$ \\
\hline TDDJ & $1,2 a, 2 c, 3,24,17,10,14 a$ \\
\hline TDRJ & $1,2 a, 2 c, 3,24,3 \mathrm{ka}, 11,30,10,14 a$ \\
\hline TFBJ & $1,2 a, 2 c, 3,24,26,10,14 a$ \\
\hline TFBS & $1,2 a, 2 c, 3,24,26, B, 10,14 a$ \\
\hline TFGJ & $1,2 a, 2 c, 3,24,26,11,10,14 a$ \\
\hline TGBJ & $1,2 a, 2 c, 3,16,10,14 a$ \\
\hline THBJ & $1,2 a, 2 c, 3,16,26,10,14 a$ \\
\hline TKBJ & $1,2 a, 2 c, 3,16,24,26,10,14 a$ \\
\hline TLGF & $1,2 a, 2 c, 3,9,11,14 a, 18$ \\
\hline TLGJ & $1,2 a, 2 c, 3,9,11,10,14 a$ \\
\hline TLGK & $1,2 a, 2 c, 3,9,11,10,14 a, 18$ \\
\hline TLMJ & $1,2 a, 2 c, 3,9,3 \mathrm{ka}, 30,10,14 a$ \\
\hline TLRF & $1,2 a, 2 c, 3,9,3 \mathrm{ka}, 11,30,14 a, 18$ \\
\hline TNBJ & $1,2 a, 2 c, 3,9,24,10,14 a$ \\
\hline TNMJ & $1,2 a, 2 c, 3,9,24,3 \mathrm{ka}, 30,10,14 a$ \\
\hline TNRJ & $1,2 a, 2 c, 3,9,24,3 k a, 11,30,10,14 a$ \\
\hline TNRS & $1,2 a, 2 c, 3,9,24,3 \mathrm{ka}, 11,30, B, 10,14 a$ \\
\hline TPGJ & $1,2 a, 2 c, 3,9,24,26,11,10,14 a$ \\
\hline
\end{tabular}

${ }^{\text {a }}$ Hexadecimal letter code for virulence phenotypes of Puccinia triticina in North America (10). 
the Great Plains region. The movement of urediniospores from south to north in the Great Plains region was originally documented for stem rust of wheat (16) and also more recently for leaf rust $(8,12)$. The populations of $P$. triticina in the Prairie Provinces of Canada also closely resemble leaf rust populations in the north central region of the United States $(4,7)$. The populations of $P$. triticina in area 4 had higher frequencies of virulence to genes Lr9, Lr24, Lr3ka, Lr11, and Lr30 com- pared with the populations in areas 5 and 6 . Wheat cultivars in area 4 may be more diverse for leaf rust resistance since cultivars with genes $L r 9, L r 24, L r 11$, and $L r 3 k a$ are present in the soft red and hard red winter wheat germ plasm adapted to this region.

Isolates with virulence to $\mathrm{Lrl6}$ were found only in the northern Great Plains region of area 6 where hard red spring and durum wheats are grown. Hard red spring wheats with Lrl6 are commonly grown in area 6 and in the adjacent regions of Canada $(4,7)$. Isolates virulent to Lrl6 may be at levels too low to detect in areas 4 and 5 in the absence of host cultivars with $\mathrm{Lr} 16$ that would select for $\mathrm{Lr} 16$ virulence. Similarly, a greater frequency of isolates with virulence to $L r 9, L r 24, L r 11$, and $L r 3 k a$ might be detected in areas 5 and 6 if wheat cultivars with these genes were more common in the mid and northern plains regions. In the absence of cultivars with $L r 9, L r 24, L r 11$, and $L r 3 k a$, in the northern

Table 2. Number and frequency (\%) of virulence phenotypes of Puccinia triticina in the United States in 2000, identified on 16 lines of Thatcher wheat near-isogenic for leaf rust resistance genes

\begin{tabular}{|c|c|c|c|c|c|c|c|c|c|c|c|c|c|c|c|c|}
\hline \multirow{2}{*}{$\begin{array}{l}\text { Virulence } \\
\text { phenotype }\end{array}$} & \multicolumn{2}{|c|}{ Area 1a } & \multicolumn{2}{|c|}{ Area 2} & \multicolumn{2}{|c|}{ Area 3} & \multicolumn{2}{|c|}{ Area 4} & \multicolumn{2}{|c|}{ Area 5} & \multicolumn{2}{|c|}{ Area 6} & \multicolumn{2}{|c|}{ Area 7} & \multicolumn{2}{|c|}{ Total } \\
\hline & $\#$ & $\%$ & $\#$ & $\%$ & $\#$ & $\%$ & $\#$ & $\%$ & $\#$ & $\%$ & $\#$ & $\%$ & $\#$ & $\%$ & $\#$ & $\%$ \\
\hline DBBK & 0 & 0 & 2 & 7.4 & 0 & 0 & 0 & 0 & 0 & 0 & 0 & 0 & 0 & 0 & 2 & 0.2 \\
\hline FBMT & 4 & 1.1 & 0 & 0 & 2 & 1.9 & 0 & 0 & 0 & 0 & 0 & 0 & 0 & 0 & 6 & 0.5 \\
\hline LBBR & 0 & 0 & 2 & 7.4 & 0 & 0 & 0 & 0 & 0 & 0 & 0 & 0 & 0 & 0 & 2 & 0.2 \\
\hline MBBJ & 2 & 0.6 & 0 & 0 & 0 & 0 & 0 & 0 & 0 & 0 & 0 & 0 & 2 & 5.6 & 4 & 0.4 \\
\hline MBDJ & 4 & 1.1 & 0 & 0 & 0 & 0 & 0 & 0 & 0 & 0 & 0 & 0 & 0 & 0 & 4 & 0.4 \\
\hline MBDS & 0 & 0 & 0 & 0 & 21 & 19.4 & 52 & 31.9 & 69 & 74.2 & 112 & 33.3 & 0 & 0 & 254 & 22.7 \\
\hline MBGJ & 0 & 0 & 0 & 0 & 0 & 0 & 0 & 0 & 0 & 0 & 0 & 0 & 27 & 75.0 & 27 & 2.4 \\
\hline MBNJ & 0 & 0 & 0 & 0 & 0 & 0 & 0 & 0 & 0 & 0 & 2 & 0.6 & 0 & 0 & 2 & 0.2 \\
\hline MBRJ & 0 & 0 & 4 & 14.8 & 8 & 7.4 & 7 & 4.3 & 0 & 0 & 0 & 0 & 0 & 0 & 19 & 1.7 \\
\hline MBRK & 54 & 15.1 & 0 & 0 & 21 & 19.4 & 0 & 0 & 0 & 0 & 2 & 0.6 & 0 & 0 & 77 & 6.9 \\
\hline MBRS & 0 & 0 & 0 & 0 & 4 & 3.7 & 0 & 0 & 0 & 0 & 0 & 0 & 0 & 0 & 4 & 0.4 \\
\hline MCBS & 0 & 0 & 4 & 14.8 & 0 & 0 & 0 & 0 & 0 & 0 & 0 & 0 & 0 & 0 & 4 & 0.4 \\
\hline MCDS & 4 & 1.1 & 0 & 0 & 6 & 5.6 & 16 & 9.8 & 16 & 17.2 & 72 & 21.4 & 2 & 5.6 & 116 & 10.4 \\
\hline MCMJ & 2 & 0.6 & 0 & 0 & 4 & 3.7 & 0 & 0 & 0 & 0 & 0 & 0 & 0 & 0 & 6 & 0.5 \\
\hline MCRK & 116 & 32.5 & 6 & 22.2 & 11 & 10.2 & 2 & 1.2 & 0 & 0 & 2 & 0.6 & 0 & 0 & 137 & 12.2 \\
\hline MDBJ & 0 & 0 & 0 & 0 & 0 & 0 & 3 & 1.8 & 0 & 0 & 1 & 0.3 & 0 & 0 & 4 & 0.4 \\
\hline MDMJ & 0 & 0 & 0 & 0 & 0 & 0 & 3 & 1.8 & 0 & 0 & 0 & 0 & 0 & 0 & 3 & 0.3 \\
\hline MDRJ & 2 & 0.6 & 0 & 0 & 0 & 0 & 0 & 0 & 3 & 3.2 & 2 & 0.6 & 1 & 2.8 & 8 & 0.7 \\
\hline MDRK & 2 & 0.6 & 0 & 0 & 0 & 0 & 0 & 0 & 0 & 0 & 0 & 0 & 0 & 0 & 2 & 0.2 \\
\hline PBGR & 0 & 0 & 0 & 0 & 1 & 0.9 & 0 & 0 & 0 & 0 & 0 & 0 & 0 & 0 & 1 & 0.1 \\
\hline PCMR & 2 & 0.6 & 2 & 7.4 & 0 & 0 & 0 & 0 & 0 & 0 & 0 & 0 & 0 & 0 & 4 & 0.4 \\
\hline PCRK & 2 & 0.6 & 0 & 0 & 0 & 0 & 0 & 0 & 0 & 0 & 0 & 0 & 0 & 0 & 2 & 0.2 \\
\hline PNMQ & 1 & 0.3 & 0 & 0 & 0 & 0 & 0 & 0 & 0 & 0 & 0 & 0 & 0 & 0 & 1 & 0.1 \\
\hline TBBJ & 2 & 0.6 & 0 & 0 & 2 & 1.9 & 5 & 3.1 & 0 & 0 & 6 & 1.8 & 0 & 0 & 15 & 1.3 \\
\hline TBDS & 0 & 0 & 0 & 0 & 0 & 0 & 2 & 1.2 & 0 & 0 & 13 & 3.9 & 0 & 0 & 15 & 1.3 \\
\hline TBRJ & 0 & 0 & 0 & 0 & 1 & 0.9 & 0 & 0 & 3 & 3.2 & 0 & 0 & 4 & 11.1 & 8 & 0.7 \\
\hline TBRK & 4 & 1.1 & 0 & 0 & 2 & 1.9 & 0 & 0 & 0 & 0 & 0 & 0 & 0 & 0 & 6 & 0.5 \\
\hline TCBB & 0 & 0 & 0 & 0 & 0 & 0 & 0 & 0 & 0 & 0 & 2 & 0.6 & 0 & 0 & 2 & 0.2 \\
\hline TCBJ & 0 & 0 & 0 & 0 & 4 & 3.7 & 4 & 2.5 & 0 & 0 & 21 & 6.3 & 0 & 0 & 29 & 2.6 \\
\hline TCBS & 8 & 2.2 & 0 & 0 & 0 & 0 & 9 & 5.5 & 0 & 0 & 19 & 5.7 & 0 & 0 & 36 & 3.2 \\
\hline TCDS & 0 & 0 & 0 & 0 & 0 & 0 & 3 & 1.8 & 0 & 0 & 12 & 3.6 & 0 & 0 & 15 & 1.3 \\
\hline TCMJ & 0 & 0 & 0 & 0 & 2 & 1.9 & 0 & 0 & 0 & 0 & 0 & 0 & 0 & 0 & 2 & 0.2 \\
\hline TCMS & 0 & 0 & 0 & 0 & 0 & 0 & 3 & 1.8 & 0 & 0 & 0 & 0 & 0 & 0 & 3 & 0.3 \\
\hline TCRJ & 30 & 8.4 & 2 & 7.4 & 8 & 7.4 & 6 & 3.7 & 2 & 2.2 & 0 & 0 & 0 & 0 & 48 & 4.3 \\
\hline TCRK & 11 & 3.1 & 0 & 0 & 2 & 1.9 & 0 & 0 & 0 & 0 & 0 & 0 & 0 & 0 & 13 & 1.2 \\
\hline TDBJ & 0 & 0 & 0 & 0 & 1 & 0.9 & 2 & 1.2 & 0 & 0 & 2 & 0.6 & 0 & 0 & 5 & 0.4 \\
\hline TDDJ & 2 & 0.6 & 0 & 0 & 0 & 0 & 0 & 0 & 0 & 0 & 0 & 0 & 0 & 0 & 2 & 0.2 \\
\hline TDRJ & 3 & 0.8 & 0 & 0 & 0 & 0 & 0 & 0 & 0 & 0 & 0 & 0 & 0 & 0 & 3 & 0.3 \\
\hline TFBJ & 0 & 0 & 0 & 0 & 0 & 0 & 16 & 9.8 & 0 & 0 & 10 & 3.0 & 0 & 0 & 26 & 2.3 \\
\hline TFBS & 0 & 0 & 0 & 0 & 0 & 0 & 0 & 0 & 0 & 0 & 2 & 0.6 & 0 & 0 & 2 & 0.2 \\
\hline TFGJ & 2 & 0.6 & 0 & 0 & 0 & 0 & 0 & 0 & 0 & 0 & 0 & 0 & 0 & 0 & 2 & 0.2 \\
\hline TGBJ & 0 & 0 & 0 & 0 & 0 & 0 & 0 & 0 & 0 & 0 & 1 & 0.3 & 0 & 0 & 1 & 0.1 \\
\hline THBJ & 0 & 0 & 0 & 0 & 0 & 0 & 0 & 0 & 0 & 0 & 46 & 13.7 & 0 & 0 & 46 & 4.1 \\
\hline TKBJ & 0 & 0 & 0 & 0 & 0 & 0 & 0 & 0 & 0 & 0 & 6 & 1.8 & 0 & 0 & 6 & 0.5 \\
\hline TLGF & 40 & 11.2 & 5 & 18.5 & 0 & 0 & 3 & 1.8 & 0 & 0 & 0 & 0 & 0 & 0 & 48 & 4.3 \\
\hline TLGJ & 27 & 7.6 & 0 & 0 & 0 & 0 & 2 & 1.2 & 0 & 0 & 0 & 0 & 0 & 0 & 29 & 2.6 \\
\hline TLGK & 4 & 1.1 & 0 & 0 & 0 & 0 & 0 & 0 & 0 & 0 & 0 & 0 & 0 & 0 & 4 & 0.4 \\
\hline TLMJ & 0 & 0 & 0 & 0 & 0 & 0 & 0 & 0 & 0 & 0 & 2 & 0.6 & 0 & 0 & 2 & 0.2 \\
\hline TLRF & 0 & 0 & 0 & 0 & 2 & 1.9 & 0 & 0 & 0 & 0 & 0 & 0 & 0 & 0 & 2 & 0.2 \\
\hline TNBJ & 0 & 0 & 0 & 0 & 0 & 0 & 4 & 2.5 & 0 & 0 & 0 & 0 & 0 & 0 & 4 & 0.4 \\
\hline TNMJ & 8 & 2.2 & 0 & 0 & 4 & 3.7 & 7 & 4.3 & 0 & 0 & 0 & 0 & 0 & 0 & 19 & 1.7 \\
\hline TNRJ & 21 & 5.9 & 0 & 0 & 0 & 0 & 8 & 4.9 & 0 & 0 & 0 & 0 & 0 & 0 & 29 & 2.6 \\
\hline TNRS & 0 & 0 & 0 & 0 & 2 & 1.9 & 4 & 2.5 & 0 & 0 & 1 & 0.3 & 0 & 0 & 7 & 0.6 \\
\hline TPGJ & 0 & 0 & 0 & 0 & 0 & 0 & 2 & 1.2 & 0 & 0 & 0 & 0 & 0 & 0 & 2 & 0.2 \\
\hline Total & \multicolumn{2}{|c|}{357} & \multicolumn{2}{|c|}{27} & \multicolumn{2}{|c|}{108} & & & & & & & & & & \\
\hline
\end{tabular}

a Area 1, southeastern states; area 2, northeastern states; area 3, Ohio Valley states; area 4, southern Great Plains; area 5, mid-Plains states; area 6, northern Great Plains. 
Great Plains, isolates of $P$. triticina with virulence to these genes may have a fitness disadvantage, thus reducing their frequency of occurrence.

Phenotype MBGJ was the most common phenotype in California (area 7) and was not found in any other region of the United States in 2000. MBGJ was once widespread over the entire United States (11), but has declined in recent years with the selection and increase of phenotypes MBDS, MCDS, MCRK, and TLGF in different regions of the country. The population of $P$. triticina in California is relatively isolated from the other wheat growing regions of the country.

Virulence phenotypes that have low infection type to $\operatorname{Lr} 2 a$ and high infection to Lr2c (D---, F---, and P---) were found in 2000 in areas 1, 2, and 3. Virulence phenotypes with either low or high infection to both $L r 2 a$ and $L r 2 c$ (M--- and T---) were found in all regions in 2000. A single phenotype of LBBR (low infection type to both $L r 2 a$ and $L r 2 c$ ) was found in area 2 in 2000. In Canada, P---, M---, and T--- phenotypes have been found in the eastern provinces of Ontario and Quebec, and also in British Columbia and Alberta $(4,5,7)$.

In 2000, virulence to $\operatorname{Lr} 9$ was found in 10 T--- virulence phenotypes and also PNMQ. Most of the phenotypes with virulence to $L r 9$ were collected in areas 1,2, or 3. In 1999, virulence to $\operatorname{Lr} 9$ was found in six T--- phenotypes and also in PNMQ (12). Virulence to Lrl6 was found in only three phenotypes in 2000 (THBJ, TGBJ, TKBJ) and in two phenotypes (TGBJ, THBJ) in 1999. Selection for isolates with virulence to $\operatorname{Lr} 16$ is likely occurring only in the spring wheat region of area 6, since wheat cultivars with $\operatorname{Lrl6}$ are not widely grown in other regions.

Virulence to $L r 24$ and $L r 26$ are now widely distributed in the population of $P$. triticina, being found in 17 and 21 different virulence phenotypes, respectively, in 2000. Virulence to $L r 24$ and $L r 26$ were initially limited to a few phenotypes of $P$. triticina when these genes were initially introduced in wheat cultivars in the early 1970s and mid 1980s, respectively. In 2000 across the entire United States, virulence frequencies to $L r 24$ and $\operatorname{Lr} 26$ were 11.2 and $44.7 \%$, respectively. In 1986, virulence to $L r 24$ and $L r 26$ was 1 and $2 \%$, respectively.

Virulence to $\operatorname{Lr} 17$ in 2000 was found in seven virulence phenotypes of $P$. triticina and occurred in $36.4 \%$ of all isolates. In 1996, virulence to $\operatorname{Lrll}$ occurred in only $9 \%$ of the overall population. The MBDS and MCDS phenotypes that are virulent to Lrl7 were likely introduced to the United States since these isolates have distinct molecular variation and also differ from most other isolates in areas 4, 5, and 6 for virulence to three other leaf rust resistance genes (6).

Virulence to $L r 11$ was found in 23 virulence phenotypes of $P$. triticina in 2000, and was in $42.7 \%$ of all isolates. Numerous soft red winter wheat cultivars grown in the southeastern states of area 1 have Lrll, as do some hard red winter wheat cultivars grown in areas 4 and 5. The widespread use of wheat cultivars with Lrll has resulted in a wide array of virulence phenotypes of $P$. triticina with virulence to this gene. Virulence to $L r 3 k a$ occurred in 25 virulence phenotypes in 2000 and was found in $36.9 \%$ of all isolates. Virulence to $\mathrm{Lr} 3 \mathrm{ka}$ increased very rapidly starting in 1992 after wheat cultivars with this gene were released in Kansas (1).

Populations of $P$. triticina in the different regions of the United States continue to change on nearly a continuous basis due to the introduction of wheat cultivars with specific leaf rust resistance genes. As wheat classes with different leaf rust resistance genes are grown in the United States, it is likely that the regional populations of $P$. triticina will continue to differ for virulence phenotypes. Since populations of $P$. triticina in North America are extremely large, mutation that generates virulence variation is a recurrent event. Mutation and subsequent selection of specific virulence by host resistance genes has maintained diverse and dynamic populations of virulence phenotypes of $P$. triticina in North America.

\section{LITERATURE CITED}

1. Kolmer, J. A. 1989. Virulence and race dynamics of Puccinia recondita f. sp. tritici in Canada during 1956-1987. Phytopathology 79:349-356.

2. Kolmer, J. A. 1991. Evolution of distinct populations of Puccinia recondita f. sp. tritici in Canada. Phytopathology 81:316-322.

3. Kolmer, J. A. 1992. Diversity of virulence phenotypes and effect of host sampling between and within populations of Puccinia recondita f. sp. tritici in Canada. Plant Dis. 76:618-621.

4. Kolmer, J. A. 1999. Physiologic specialization of Puccinia triticina in Canada in 1997. Plant Dis. 83:194-197.

5. Kolmer, J. A. 1999. Virulence dynamics, phenotypic diversity, and virulence complexity in two populations of Puccinia triticina in Canada from 1987-1997. Can. J. Bot. 77:333338.

6. Kolmer, J. A. 2001. Molecular polymorphism and virulence phenotypes of the wheat leaf rust fungus Puccinia triticina in Canada. Can. J. Bot. 79:917-926.

7. Kolmer, J. A. 2001. Physiologic specialization of Puccinia triticina in Canada in 1998. Plant Dis. $85: 155-158$.

8. Leonard, K. J., Roelfs, A. P., and Long, D. L. 1992. Diversity of virulence within and among populations of Puccinia recondita $\mathrm{f}$. sp. tritici in different areas of the United States. Plant Dis. 76:500-504.

9. Long, D. L., and Hughes, M. E. 2001. Small Grain Losses to Rust. U.S. Dep. Agric. Res. Serv. Cereal Dis. Lab. On-line, publication CDL-EP\#007. Updated annually.

10. Long, D. L., and Kolmer, J. A. 1989. A North American system of nomenclature for Puccinia recondita f. sp. tritici. Phytopathology 79:525-529.

Table 3. Number and frequency (\%) of isolates of Puccinia triticina in the United States in 2000, virulent on 16 lines of Thatcher wheat near-isogenic for leaf rust resistance genes

\begin{tabular}{|c|c|c|c|c|c|c|c|c|c|c|c|c|c|c|c|c|}
\hline \multirow{2}{*}{$\begin{array}{l}\text { Resistance } \\
\text { gene }\end{array}$} & \multicolumn{2}{|c|}{ Area 1a } & \multicolumn{2}{|c|}{ Area 2} & \multicolumn{2}{|c|}{ Area 3} & \multicolumn{2}{|c|}{ Area 4} & \multicolumn{2}{|c|}{ Area 5} & \multicolumn{2}{|c|}{ Area 6} & \multicolumn{2}{|c|}{ Area 7} & \multicolumn{2}{|c|}{ Total } \\
\hline & $\#$ & $\%$ & \# & $\%$ & $\#$ & $\%$ & \# & $\%$ & $\#$ & $\%$ & $\#$ & $\%$ & $\#$ & $\%$ & \# & $\%$ \\
\hline Lrl & 353 & 98.9 & 25 & 92.6 & 106 & 98.1 & 163 & 100.0 & 93 & 100.0 & 336 & 100.0 & 36 & 100.0 & 1,112 & 99.3 \\
\hline $\operatorname{Lr} 2 a$ & 162 & 45.4 & 7 & 25.9 & 30 & 27.8 & 80 & 49.1 & 5 & 5.4 & 143 & 42.6 & 4 & 11.1 & 431 & 38.5 \\
\hline$L r 2 c$ & 171 & 47.9 & 11 & 40.7 & 33 & 30.6 & 80 & 49.1 & 5 & 5.4 & 143 & 42.6 & 4 & 11.1 & 447 & 39.9 \\
\hline Lr3 & 357 & 100.0 & 23 & 85.2 & 108 & 100.0 & 163 & 100.0 & 93 & 100.0 & 336 & 100.0 & 36 & 100.0 & 1,116 & 99.6 \\
\hline $\operatorname{Lr} 9$ & 101 & 28.3 & 5 & 18.5 & 8 & 7.4 & 30 & 18.4 & 0 & 0 & 3 & 0.9 & 0 & 0 & 147 & 13.1 \\
\hline Lr16 & 0 & 0 & 0 & 0 & 0 & 0 & 0 & 0 & 0 & 0 & 53 & 15.8 & 0 & 0 & 53 & 4.7 \\
\hline $\operatorname{Lr} 24$ & 41 & 11.5 & 0 & 0 & 7 & 6.5 & 49 & 30.1 & 3 & 3.2 & 24 & 7.1 & 1 & 2.8 & 125 & 11.2 \\
\hline $\operatorname{Lr} 26$ & 177 & 49.6 & 14 & 51.9 & 37 & 34.3 & 61 & 37.4 & 18 & 19.4 & 192 & 57.1 & 2 & 5.6 & 501 & 44.7 \\
\hline Lr3ka & 262 & 73.4 & 14 & 51.9 & 73 & 67.6 & 40 & 24.5 & 8 & 8.6 & 11 & 3.3 & 5 & 13.9 & 413 & 36.9 \\
\hline Lr11 & 318 & 89.1 & 17 & 63.0 & 62 & 57.4 & 34 & 20.9 & 8 & 8.6 & 7 & 2.1 & 32 & 88.9 & 478 & 42.7 \\
\hline Lr17 & 10 & 2.8 & 0 & 0 & 27 & 25.0 & 73 & 44.8 & 85 & 91.4 & 211 & 62.8 & 2 & 5.6 & 408 & 36.4 \\
\hline Lr30 & 262 & 73.4 & 14 & 51.9 & 73 & 67.6 & 40 & 24.5 & 8 & 8.6 & 9 & 2.7 & 5 & 13.9 & 411 & 36.7 \\
\hline $\operatorname{LrB}$ & 19 & 5.3 & 8 & 29.6 & 36 & 33.3 & 89 & 54.6 & 85 & 91.4 & 231 & 68.8 & 2 & 5.6 & 470 & 42.0 \\
\hline Lrlo & 317 & 88.8 & 22 & 81.5 & 106 & 98.1 & 160 & 98.2 & 93 & 100.0 & 334 & 99.4 & 36 & 100.0 & 1,068 & 95.4 \\
\hline $\operatorname{Lr} 14 a$ & 354 & 99.2 & 23 & 85.2 & 107 & 99.1 & 163 & 100.0 & 93 & 100.0 & 334 & 99.4 & 36 & 100.0 & 1,110 & 99.1 \\
\hline Lr18 & 239 & 66.9 & 17 & 63.0 & 41 & 38.0 & 5 & 3.1 & 0 & 0 & 4 & 1.2 & 0 & 0 & 306 & 27.3 \\
\hline Total & \multicolumn{2}{|c|}{357} & \multicolumn{2}{|c|}{27} & \multicolumn{2}{|c|}{108} & \multicolumn{2}{|c|}{163} & \multicolumn{2}{|c|}{93} & \multicolumn{2}{|c|}{336} & \multicolumn{2}{|c|}{36} & \multicolumn{2}{|c|}{1,120} \\
\hline
\end{tabular}

a Area 1, southeastern states; area 2, northeastern states; area 3, Ohio Valley states; area 4, southern Great Plains; area 5, mid-Plains states; area 6, northern Great Plains. 
11. Long, D. L., Leonard, K. J., and Hughes, M. E. 2000. Virulence of Puccinia triticina on wheat in the United States from 1996 to 1998. Plant Dis. 84:1334-1341.

12. Long, D. L., Leonard, K. J., and Hughes, M. E. 2002. Virulence of Puccinia triticina on wheat in the United States in 1999. Plant Dis. 86:15-19.

13. Long, D. L., Leonard, K. J., and Roberts, J. J.
1998. Virulence and diversity of wheat leaf rust in the United States in 1993 to 1995. Plant Dis. 82:1391-1400.

14. McIntosh, R. A., Wellings, C. R., and Park, R. F. 1995. Wheat Rusts: An Atlas of Resistance Genes. CSIRO Australia, Kluwer Academic Publishers, Dordrecht, Netherlands.

15. Singh, R. P. 1991. Pathogenicity variations of
Puccinia recondita f. $\mathrm{sp}$. tritici and $P$. graminis f. sp. tritici in wheat-growing areas of Mexico during 1988 and 1989. Plant Dis. 75:790-794.

16. Stakman, E. C., Levine, M. N., and Wallace, J. M. 1929. The value of physiologic-form surveys in the study of the epidemiology of stem rust. Phytopathology 19:951-959. 